\title{
Efektivitas Kepemimpinan Konsiderasi terhadap Employee Engagement di Rumah Singgah Yayasan Mahanaim
}

\author{
Iin Tjipto Purnomo \\ Sekolah Tinggi Theologia Kerusso Indonesia, Bekasi \\ iintjjipto.purnomo@gmail.com
}

\begin{abstract}
An organization, institution, company and even a state can be said to be successful, progressing and developing depending on the leader. Leadership is influence, to what extent the leader influences and directs the people he leads to a place, then that's where the results will be seen. One form or style of leadership is consideration leadership in which a leader pays attention to his subordinates. Consideration style or leadership style will produce family relationships and bonds of love. Subordinates will feel different, if the leader pays attention and builds family relationships.
\end{abstract}

Keywords:attention; consideration; kinship; leadership

\begin{abstract}
Abstrak
Suatu organisasi, institusi, perusahaan bahkan negara dapat dibilang berhasil, maju dan berkembang tergantung dari pemimpinnya. Kepemimpinan adalah pengaruh, sampai sejauh mana si pemimpin membawa pengaruh dan mengarahakan orang yang dipimpinnya ke suatu tempat, maka disitulah akan terlihat hasilnya. Salah satu bentuk atau gaya kepemimpinan adalah kepemimpnan konsiderasi di mana seorang pemimpin memberi perhatian kepada bawahannya. Style atau gaya kepemimpinan konsiderasi akan menghasilkan hubungan kekeluargaan dan ikatan kasih. Bawahan akan merasakan hal yang berbeda, jika pemimpinnya menaruh perhatian dan membangun hubungan secara kekeluargaan.
\end{abstract}

Kata Kunci: kekeluargaan; kepemimpinan; konsiderasi; perhatian

\section{PENDAHULUAN}

Dalam satu hingga dua dekade belakangan ini, dunia kekristenan melahirkan sejumlah besar pemimpin dengan visi dan misinya yang begitu luar biasa. Tapi seiring dengan jalannya waktu, tidak sedikit juga visi dan misi yang besar itu lalu begitu saja ditelan arus zaman tanpa penjelasan sedikit pun kepada para donator sejauh mana pencapaian yang telah dilakukan. Padahal tidak sedikit di antara mereka (para hamba Tuhan ini) jelas mengatakan bahwa visinya itu dari Tuhan. Tentu hal itu sah-sah saja, tetapi jika benar dari Tuhan semestinya apa yang Tuhan telah perlihatkan kepadanya sebelumnya itu dapat diwujudkan sedemikian rupa sehingga Tuhan dipermuliakan. 
Guna mewujudkan visi yang besar ada banyak aspek yang harus dipenuhi dan itu diperlukan tidak saja work hard, tetapi juga work smart. Berdasarkan hasil sebuah survey dari 3 faktor dominan penyebab kegagalan pemimpin, salah satunya adalah, kegagalan dalam membangun tim ${ }^{1}$ Para penulis kitab Perjanjian Baru, khususnya dalam Kitab Injil Sinoptik jelas memperlihatkan bagaimana dalam hanya kurun waktu tiga tahun lebih saja, Tuhan Yesus berhasil membangun sebuah tim yang mampu terus bekerja meskipun pemimpinnya tidak lagi ada bersama mereka dalam wujud fisik sebagaimana sebelumnya. Bahkan murid murid Yesus melakukan hal hal yang lebih dahsyat sesudah Yesus naik ke surga dan Roh Kudus dicurahkan.

Keberadaan karyawan atau staf atau rekan kerja merupakan unsur terpenting dalam sebuah organisasi apapun, termasuk lembaga-lembaga pelayanan, karena keberadaan mereka sangat berpengaruh terhadap eksistensi dan pencapaian visi misi dari lembaga tersebut. Bahkan bisa dikatakan bahwa eksis tidaknya sebuah organisasi dikemudian hari, sangat tergantung dan ditentukan oleh sejauh mana kapasitas, kredibilitas dan kapabilitas dari seluruh SDM yang tergabung dalam tim sebuah lembaga tersebut. Untuk itu, setiap lembaga pelayanan diperhadapkan dengan sebuah tantangan dalam hal mengelola dan mengatur aspek sumber daya manusia yang dimilikinya dengan sebaik mungkin.

Manajemen sumber daya manusia merupakan sarana guna meningkatkan kualitas dan kompetensi dari sumber daya manusia yang ada, dimana melaluinya diharapkan akan terjadi peningkatan kinerja dan pencapaian tujuan. Dari antara faktor-faktor penting yang berdampak secara langsung kepada peningkatan kinerja karyawan adalah gaya kepemimpinan. Gaya kepemimpinan merupakan norma perilaku yang digunakan oleh seseorang pada saat orang tersebut mencoba mempengaruhi perilaku orang lain.

Salah satu kendala yang umum dijumpai di kalangan lembaga-lembaga pelayanan di Indonesia adalah terkait dengan minimnya donatur. Atau para pendonor itu lebih concern terhadap program dari pada mereka yang bekerja di balik program tersebut. Hal ini mengakibatkan mereka yang bekerja atau melayani di lembaga tersebut harus menerima gaji atau yang lebih sering disebut PK (persembahan kasih) tidak seturut dengan UMR yang berlaku di daerah tersebut. Jadi, guna membangun employee engagement merupakan tantangan yang tidak mudah bagi para pemimpin di lembaga-lembaga pelayanan kristiani. Diperlukan sebuah pendekatan kekeluargaan yang melaluinya para staf merasa bagian dalam tim yang melaluinya mereka tidak akan tergoda untuk pindah ke pelayanan lain, meskipun hal itu adalah hak prerogatif staf. Tidak hanya itu saja, para pemimpin ditantang

${ }^{1}$ Kadek Budiawan ST, MBA, "3 Kegagalan Pemimpin", Updatelive1000, Last modified 2018, https://updatelive1000.wordpress.com/leadership-2/3-kegagalan-pemimpin/. 
untuk mampu menempatkan para stafnya sesuai dengan bakat atau talenta masing-masing. Karena dengan demikian mereka akan berkembang sedemikian rupa karena bekerja seturut dengan kapasitasnya masing-masing.

Rumah Singgah Yayasan Mahanaim yang telah berdiri sejak tahun 1998 di mana Tujuan kami adalah membantu kaum marginal dan anak anak telantar dengan memberikan bantuan yang terbaik dan tidak luput dari problema tersebut di atas. Masalah employee engagement juga menjadi problem yang besar mengingat minimnya persembahan bulanan yang diberikan. Rumah singgah Mahanaim makin berkembang dengan lebih dari 20.000 anak yang harus kita layani setiap hari. Rumah singgah mahanaim terbuka di seluruh kota di Indonesia di 34 Provinsi seperti Papua, NTT, Bekasi, Kalimantan Timur, Batam, Riau, Poso. Tentu pekerjaan yang besar ini melibatkan sejumlah besar staf yang bisa bekerja bahu membahu satu dengan lainnya. Dan semuanya itu hanya bisa berjalan dengan baik oleh karena kehadiran pemimpin dengan gaya kepemimpinan yang mampu untuk merangkul dan memotivasi seluruh tim yang ada ditambah setiap orang rumah singgah yang memiliki posisi tersebar di satu kota dan provinsi Indonesia sehingga ada kepercayaan dengan staff, baik mereka yang terlibat secara langsung kesehariannya, maupun mereka yang berkontribusi dalam bentuk dana atau lainnya. Guna mengelola dinamika yang ada dalam lembaga pelayanan, dalam hal ini Rumah Singgah Yayasan Mahanaim, dibutuhkan seorang figur pemimpin yang dapat dipercaya.

\section{METODE}

Artikel ini adalah sebuah kajian kualitatif dengan metode deskriptif, untuk memberikan gambaran tentang pentingnya sebuah kepemimpinan konsiderasi employment engagement dalam menangani pelayanan di rumah singgah Yayasan Mahanaim. Sumber yang digunakan adalah kepustakaan dan survei pada lapangan.

\section{PEMBAHASAN}

\section{Gaya Kepemimpinan Struktur Konsiderasi}

Terkait dengan faktor gaya atau perilaku pemimpin, berdasarkan hasil penelitian dari Bureau of Business Research Universitas Ohio diketahui bahwa terdapat 2 (dua) aspek yang harus diperhatikan dan salah satunya yaitu: consideration, Gaya Kepemimpinan struktur konsiderasi ini mencerminkan, perilaku pemimpin cenderung ke arah kepentingan bawahan. Ada pun ciri-ciri kepemimpinan konsiderasi ini yakni sebagai berikut:

1. Selalu memberikan dukungan kepada bawahan.

2. Memberikan proteksi. 
3. Mendengarkan dan menerima usul atau saran dari bawahan.

4. Sangat memperhatikan kesejahteraan karyawan.

5. Menempatkan dirinya setingkat dengan bawahan.

Dalam kenyataannya, pemimpin yang lebih berorientasi pada karyawan dalam beberapa hal akan memberkan hasil-hasil yang lebih efektif. Ini tidak berarti pemimpin tersebut mengabaikan kebutuhan-kebutuhan produksi atau tugas dalam departemennya,Kepemimpinanyang berhasil menghendaki suatu pengertian yang mendalam terhadap bawahan.

Gaya kepemimpinan Struktur Konsiderasi merupakan Gaya Kepemimpinan yang berorientasi kepada bentuk perhatian pimpinan kepada bawahan. Teori yang mendukung orientasi kepemimpinan ini adalah studi Ohio dan Michigan dalam kutipan jurnal ilmiah manajemen dan bisnis vol. 04, 2004. Perilaku kepemimpinan ini lebih banyak menunjukkan persahabatan, saling mempercayai, rasa hormat, kehangatan, dan hubungan antara pemimpin dan pengikut. Sedangkan menurut Veithzal Rifai. ${ }^{2}$

Gaya kepemimpinan struktur konsiderasi adalah gaya kepemimpin yang berorientasi kepada perilaku hubungan antara atasan dan bawahan. Kepemimpinan ini menekankan kepada persahabatan, saling mempercayai dan hubungan pemimpin dan bawahan. Dalam struktur konsiderasi ini, pemimpin menganggap para pegawai adalah penting dan merupakan bagian dari organisasi. Pimpinan selalu memberikan motivasi memenuhi kebutuhan pegawai, serta bawahan terlibat dalam pengambilan keputusan. Hal demikian dapat diketahui sejauhmana tingkat hubungan antara pimpinan dan bawahan, dan tingkat tersebut pula oleh situasi dan kondisi yang sedang dihadapi oleh pimpinan.

\section{Employee Engagement}

Kata "engage" memiliki berbagai makna dan banyak peneliti yang memiliki pengertian berbeda mengenai engagement. ${ }^{3}$ Ketika individu sangat peduli dengan apa yang ia lakukan dan komitmen untuk melakukan hal itu sebaik mungkin, ia akan merasa terdorong untuk berbuat daripada hanya diam. Inilah bagian dari engagement. ${ }^{4}$ Employee engagement adalah hasrat anggota organisasi terhadap pekerjaan mereka dimana mereka bekerja dan mengekspresikan diri mereka secara fisik, kognitif, dan emosi selama melakukan pekerjaan. ${ }^{5}$

\footnotetext{
${ }^{2}$ Veithzal Rivai dan Sagala, Ella Jauvani. Manajemen Sumber Daya Manusia untuk Perusahaan dari Teori ke Praktik. (Jakarta: PT Raja Grafindo, 2010), hal 62

${ }^{3}$ Albrecht, L. S..Handbook of employee engagement, (Northamptom: Edward Elgar Press, 2010), pp 65

${ }^{4}$ W. A.Kahn, (1990). Psychological Conditions Of Personal Engagement And Disengagement At Work. Academy of management journal Vol. 33,

${ }^{5}$ Albrecht, L. S., Op. Cit.,
} 
Definisi berbeda diungkapkan oleh Thomas Henryhandyang menyatakan bahwa employee engagement direpresentasikan sebagai hubungan dua arah antara karyawan dan organisasi dimana kedua pihak ini sadar akan kebutuhan satu sama lain dan bekerja sama untuk memenuhi kebutuhan tersebut. ${ }^{6}$ Conference Board menyebutkan bahwa engagement pada karyawan adalah sebuah hubungan yang kuat secara emosional dan intelektual yang dimiliki oleh karyawan terhadap pekerjaannya, organisasi, manajer atau rekan kerja, yang pada gilirannya, akan mempengaruhi dia untuk memberikan upaya lebih pada pekerjaanya. $^{7}$

Definisi lain juga diungkapkan oleh Lockwood bahwa employee engagement sebagai penyataan oleh individu secara emosional dan intelektual komitmen terhadap organisasi, yang diukur melalui tiga perilaku utama:

Berbicara positif mengenai organisasi kepada rekan kerja dan pelanggan;

Memiliki gairah yang intens untuk menjadi anggota organisasi, meski sebenarnya mendapat peluang kerja di tempat lain;

Menunjukkan usaha ekstra dan perilaku yang memiliki kontribusi terhadap kesuksesan organisasi. ${ }^{8}$

Dari beberapa pengertian di atas, maka dapat disimpulkan bahwa employee engagement merupakan keadaan di mana karyawan merasa positif dan puas terhadap pekerjaannya yang ditandai dengan adanya vigor (semangat), dedication (dedikasi) dan absorption (keasyikan) pada karyawan. Engagement bukanlah hal yang bersifat sementara dan merujuk pada keadaan tertentu, tapi lebih pada kondisi yang lebih terus menerus dan merupakan bentuk kesadaran yang terjadi tanpa dipengaruhi oleh kejadian, objek, dan perilaku tertentu.

\section{Anak dan Keluarga Kaum Marginal}

Pelayanan di Yayasan Mahanaim banyak menyentuh kaum marginal, yaitu mereka yang "terpinggirkan" tidak disentuh atau diperhatikan. Salah satunya anak jalanan. Penghormatan negara atas hak-hak anak jalanan dinilai masih sangat minim, bahkan pada kebijakan-kebijakan tertentu seperti razia-razia yang sarat dengan nuansa kekerasan, negara kerapkali dinilai melakukan pelanggaran terhadap hak-hak anak (jalanan). Kebijakankebijakan pemerintah dalam rangka memenuhi hak-hak anak jalanan harus senantiasa ditingkatkan. Hal ini mengingat anak sebagai aset dan generasi penerus bangsa. Salah

\footnotetext{
${ }^{6}$ Henryhand, C.J. (2009). The effect of employee recognition and employee engagement on job satisfaction and intent to leave in the public sector (Doctoral dissertation). United States : Capella University.

${ }^{7}$ Vibrayani. 2012. Peran Transformasional Leadership terhadap Employee Engagement. UGM: Tesis Fakultas Ekonomika dan Bisnis, 10

${ }^{8}$ Lockwood, N. 2007. Leveraging Employee Engagement for Competitive Advantage HR Strategic Role. SHRM Research, h.
} 
satunya adalah dengan meningkatkan pelayanan pendidikan bagi anak-anak jalanan. Pendidikan yang dimaksudkan disini adalah pendidikan formal sebagaimana yang dicanangkan pemerintah dalam Gerakan Wajib Belajar 9 tahun dan tentu saja dengan biaya pendidikan gratis atau murah bagi anak-anak jalanan yang memiliki keluarga miskin. Untuk menjangkau mereka-mereka inilah TUHAN membentuk Mahanaim. Karena hal-hal seperti inilah Mahanaim lahir dan ada.

Dari kebutuhan mendasar anak-anak itu, berdirilah Rumah Singgah yang pertama. Semua anak boleh datang waktu yang ditentukan. Untuk yang sekolah siang, mereka bisa datang pukul 09:00-12.00. Dan yang sekolah pagi, mereka datang pukul 15:00-18:00. Ada banyak yang dibuat di rumah singgah. Yang pertama mereka membutuhkan makanan jasmani, jiwani, dan rohani. Jadi kami memberi makanan sehat secukupnya. Seringkali itu adalah satu-satunya makanan yang mereka makan dalam hari itu karena mereka harus sekolah, kerja, mengemis, dan belajar menyelesaikan tugas-tugas. Jadi, betapa pentingnya satu piring nasi dan sayur yang kami berikan. Itu menjadi sumber energi dan sumber gizi untuk semua anak-anak yang terlantar dan yang miskin.

Selain itu, Rumah Singgah Mahanaim memberi pelajaran karakter yang mungkin adalah hal-hal yang sangat biasa tentang sopan santun, pengharapan, dan sampai kepada keselamatan. Seringkali kami memberikan pelukan dan belaian. Itu membuat mereka sadar bahwa mereka dihargai dan diingini, bukan anak-anak yang ditolak dan dibuang. Pembentukan karakter sangat nyata terjadi dengan kasih yang selalu menembusi setiap hati. Kasih tidak pernah gagal.

Rumah Singgah Mahanaim juga memberikan bimbingan belajar seperti matematika, fisika, bahasa Inggris dan sebagainya. Ini adalah Rumah Singgah untuk mereka belajar, makan, tetapi terutama untuk berjumpa dengan kasih dari Tuhan dan manusia. Sesuatu selalu menyentuh dan mengubah manusia jika muncul dari hati.

\section{Kepemimpinan di Rumah Singgah Yayasan Mahanaim}

Rumah Singgah Yayasan Mahanaim saat ini memiliki beberapa unit pelayanan yang bernaung dalam suatu lingkup Yayasan yang sama. Unit pelayanan tersebut telah berkembang sedemikian rupa sehingga masing-masing unit telah memiliki struktur kepemimpinan sendiri. Dalam unit pelayanan di Rumah Singgah Mahanaim, pemimpin cabang rumah singgah bertanggung jawab untuk menaungi beberapa pos rumah singgah, dalam pelaksanaan operasional kegiatan pelayanan rumah singgah, setiap pemimpin cabang dibantu oleh staf-staf pengajar di pos-pos rumah singgah tersebut. Setiap bulan para staf memberikan laporan pelayanan kepada pemimpin rumah singgah, dan kemudian laporan tersebut akan dilanjutkan kepada pimpinan unit Rumah Singgah Yayasan Mahanaim. 
Hubungan kekeluargaan antara pempinan dan staf terjalin dengan konsep sebuah keluarga, hal ini didorong oleh terbangunnya hubungan yang terus dikembangkan dan ditumbuhkan dengan sebuah keterbukaan, pengertian, menguatkan pada waktu salah seorang dari kita sedang lemah, saling mendoakan dan itulah yang menghasilkan sebuah ikatan diantara para pekerja. Kami belajar dan bertumbuh bersama Sebuah perbedaan bukanlah halangan untuk mencapai tujuan dan visi Rumah Singgah Yayasan Mahanaim. pada komunikasi antara pemimpin dan staf yang berlangsung dengan baik.

\section{KESIMPULAN}

Peranan pimpinan yang terlihat sangat nyata dalam memberikan motivasi kepada staf pengerja, hal ini dilakukan dengan baik melalui khotbah-khotbah yang membangkitkan iman dan pengharapan setiap staf. Setiap staf termotivasi untuk memberikan yang terbaik dalam setiap tanggung jawab yang mereka kerjakan, dengan tujuan melakukannya sebagai bentuk penyembahan kepada Tuhan. Rasa cinta kepada Tuhan menjadi salah satu energi terbesar bagi seseorang untuk melakukan segala sesuatu dengan memberikan yang terbaik. Setiap staf dilibatkan aktif dalam setiap pengambilan keputusan-keputusan dalam Rumah Singgah Yayasan Mahanaim. Melalui pertemuan-pertemuan rutin, para staf merasakan peranan aktif mereka dalam setiap kebijakan-kebijakan yang diputuskan oleh pemimpin. Komunikasi dalam setiap pertemuan-pertemuan berlangsung dengan dua arah, dimana pemimpin membagikan visi-visi pelayanan, sedangkan para staf memberikan ide-de dan masukan mereka untuk dapat merealisasikan visi tersebut dalam pelayanan di Rumah Singgah yayasan Mahanaim. Kepemimpinan tidak berlangsung dengan otoriter, tetapi bersifat terbuka dan dinamis.

Keterbukaan dalam kepemimpinan di Rumah Singgah Yayasan Mahanaim juga terlihat dengan jelas, hubungan yang terbangun antara pemimpin dan staf melalui komunikasi dua arah menciptakan kepercayaan dari setiap staf kepada kepemimpinan yang ada. Hal sangat berdampak postif dalam pencapaian visi pelayanan di Rumah Singgah Yayasan Mahanaim. Pendelegasian dan pelatihan kemampuan terhadap setiap staf dilaksanakan dengan berkala. Setiap orang ditempatkan di posisi yang sesuai dengan kemampuan/skill masing-masing, dan diberikan tanggung jawab untuk mengerjakan tugas masing-masing. Selain itu juga ada pelatihan-pelatihan yang diberikan untuk meningkatkan skill dan kemampuan setiap staf di Rumah Singgah Yayasan mahanaim. Kegiatan ini berlangsung secara berkala, dan mengikuti perkembangan dari setiap bidang yang dipercayakan. 
KHARISMATA: Jurnal Teologi Pantekosta, Vol 1, No 2, Januari 2019

\section{REFERENSI}

Albrecht, L. S..Handbook of employee engagement, Northamptom: Edward Elgar Press, 2010

Avolio, Bruce J. and William L Gardner. Authentic Leadership Development: Getting to the root of positive forms of leadership, Nebraska: Gallup Leadership Institute, 2005

Babcock-Roberson, M. E., and Strickland, O. J., "The Relationship between Charismatic Leadership, Work Engagement and Organizational Citizenship Behaviors, " Journal of Psychology, 2010

Blanchard Ken \& Hodges Phil, Lead Like Jesus, Belajar dari Model Kepemimpinan Paling Dahsyat Sepanjang Zaman, penerjemah: Dinonisius Pare, (Jakarta: Visi Media, 2007

Henryhand, C.J, The effect of employee recognition and employee engagement on job satisfaction and intent to leave in the public sector (Doctoral dissertation). United States : Capella University. 2009

Lockwood, N, Leveraging Employee Engagement for Competitive Advantage HR Strategic Role. SHRM Research, 2007

Marciano, Paul L. Carrots and Sticks Don't Work Build a Culture of Employee Engagement with the Principles of RESPECT, Mexico : McGraw Hill. 2010

Maxwell. John C. Developing the Leaders Within You, Nasville: Thomas Nelson, 1993

R. Stephen Covey, Principle Centered Leadership (Kepemimpinan yang Berbrinsip), alih bahasa: Julius Sanjaya, Jakarta: Binarupa Aksara, 1997

Veithzal Rivai dan Sagala, Ella Jauvani. Manajemen Sumber Daya Manusia untuk Perusahaan dari Teori ke Praktik., Jakarta: PT Raja Grafindo, 2010

Vibrayani, Peran Transformasional Leadership Terhadap Employee Engagement. UGM: Tesis Fakultas Ekonomika dan Bisnis, 2012

W. A. Kahn, (1990). Psychological Conditions Of Personal Engagement And Disengagement At Work. Academy of management journal Vol. 33 